\title{
The evolution of a pollen diet: Host choice and diet breadth of Andrena bees (Hymenoptera: Andrenidae)*
}

\author{
Leah L. LARKIN ${ }^{1,3}$, John L. NeFF $^{2}$, Beryl B. SIMPSON ${ }^{1}$ \\ ${ }^{a}$ Section of Integrative Biology, The University of Texas at Austin, Austin, Texas 78712, USA \\ ${ }^{\mathrm{b}}$ Central Texas Melittological Institute, Austin, TX 78731, USA \\ ${ }^{\mathrm{c}}$ Present address: Department of Biology and Museum of Southwestern Biology, MSC 032020 , \\ University of New Mexico, Albuquerque, NM 87131, USA
}

Received 18 June 2007 - Revised 1 November 2007 - Accepted 14 November 2007

\begin{abstract}
We investigate of two aspects of pollen diet of Andrena bees: the evolution of diet breadth within nearctic representatives of the genus, which includes both polylectic and oligolectic species; and host choice within an oligolectic clade of Andrena. We also evaluate phenology. Traits were mapped onto a molecular phylogeny to identify the ancestral character states. Overall, oligolecty appears to be the basal state within Andrena, and broader diets have evolved a number of times, suggesting that specialization is not a "dead end". Within the oligolectic clade studied, host shifts occur predominantly between members of the same plant tribe, indicating a phylogenetic constraint to host-usage; however, shifts to other tribes are not uncommon, and may lead to adaptive radiation. Additionally, some lineages retain the ability to use pollen from an ancestral host-plant tribe. Finally, we find a correlation between using host plants in the family Asteraceae and fall emergence.
\end{abstract}

Andrena / diet breadth / host choice / pollen / specialization

\section{INTRODUCTION}

Bee larvae feed mainly on pollen, a plant tissue, and are thus herbivores. Bees, however, are usually omitted from discussions of the evolution of host choice among phytophagous insects (e.g., Jaenike 1990; Mayhew, 1997; but see Bernays, 1988). This neglect may be attributed to the often mutualistic nature of pollination and the apparent lack of chemical defenses in pollen, both of which distinguish pollen collecting from the clearly antagonistic interaction of phytophagy. However, even effective pollinators, if suboptimal, may be viewed as competing with both the plant and the optimal pollinator for pollen (Thomson et al., 2000). Also, differential performance of some bees on alternate types of

Corresponding author: L.L. Larkin, leah_perle@alum.swarthmore.edu

* Manuscript editor: Bryan Danforth pollen (Guirguis and Brindley, 1974; Levin and Haydak, 1957; Williams, 2003) suggests that not all pollen is created (chemically) equal.

Like other herbivores, bees exhibit a range of diet breadth, from broadly generalist (polylectic) to narrowly specialist (oligolectic). Why some bees restrict their diets while others are nearly catholic in their tastes has long intrigued bee biologists (Cruden, 1972; Linsley, 1958; Robertson, 1925; Wcislo and Cane, 1996) who have proposed a variety of models to explain the evolution of host choice. The few pioneering studies which have attempted to address the evolution of pollen specificity are not backed by rigorous phylogenetic hypotheses (e.g., Moldenke, 1979a; Müller, 1996; see Larkin, 2002, Appendix D).

Perhaps half of all bees are oligolectic (Michener, 2007). True oligolectic bees collect pollen from a limited number of 
phylogenetically related host plants, either within a genus, tribe or family, across the geographic range of the bee species. Only when the host plant is locally scarce, as in years of drought or towards the end of the flowering season, will oligolectic bees utilize other plants (Linsley and MacSwain, 1958; JLN, personal observation). In the extreme, and rare, case of monolecty, only one host species is visited (e.g., Cane et al., 1996). In contrast, polylectic species collect from a wide range of unrelated host plants, although they may specialize in the short term (e.g., fidelity in honey bees and bumblebees); this behavior should not be confused with true oligolecty (Faegri and van der Pijl, 1979).

Little is truly known about the evolution of diet breadth in bees. The traditional view of floral host choice and feeding behavior in general has been that it evolved unidirectionally, from generalist to specialist (Michener, 1954; Linsley, 1958; MacSwain et al., 1973; Iwata, 1976; Moldenke, 1979a, b; Hurd et al., 1980) and that subsequent host shifts are to closely related plants. Rarer shifts to distantly related plants are thought to lead to adaptive radiations. Some data supports this. Oligolecty appears twice in a phylogeny of Lasioglossum (Danforth et al., 2003), in $L$. (Hemihalictus) lustrans and again in the two L. (Sphecodogastra) species. In both cases it is derived. Moldenke (1979a) found no evidence for evolution of polylecty from oligolecty. On the other hand, Kratochwil $(1984,1991)$ and Cane and Eickwort (unpublished manuscript) suggested that oligolecty may be the primitive condition in higher bee taxa. Wcislo and Cane (1996) supported the idea of multiple evolutionary origins of oligolecty but were unable to polarize the evolution of diet breadth without a phylogeny of bees as a whole. Michener (2007) aired the merits of both viewpoints. Thus, the idea of evolution toward feeding specificity is predominantly a theoretical construct.

Studies of other phytophagous insects indicate that avoidance of competition and/or predators may mediate host choice as much as nutritional content of the host itself (Bernays, 1988; Bernays and Chapman, 1994), or that neurological limitations, such as the ability to recognize and manipulate multiple hosts, may explain specificity better than the quality of the chosen food (Bernays, 2001). In these contexts, generalist behavior should be derived.

Only one study has addressed the evolution of diet breadth in a modern phylogenetic context: Müller (1996) reported four shifts from oligolecty to polylecty within 72 Old World anthidiine species (two additional shifts could not be polarized), as well as eight transitions to new host taxa within oligolectic lineages. However, a re-analysis of his data set (Larkin, 2002, Appendix D) resulted in a tree with little resolution, such that polarization could not be ascertained. In both Müller's original analysis and Larkin's reanalysis, diet breadth at the root of the tree was equivocal.

In the only other study to address host choice phylogenetically, Sipes and Wolf (2001) investigated host shifting within an oligolectic genus of emphorine bees, Diadasia, known to use hosts in five distantly related families. They found that four independent shifts to novel hosts occurred from an ancestral host in the Malvaceae. As Diadasia belongs to the tribe Emphorini, whose members are entirely oligolectic, the authors did not attempt to assess whether oligolecty was an ancestral or derived trait overall.

The genus Andrena (Andrenidae) is an excellent group with which to study the evolution of pollen diet because it includes both polylectic and oligolectic taxa, the latter specializing on many plant taxonomic groups, including Asteraceae, Brassicaceae, Cornaceae, Cucurbitaceae, Ericaceae, Fabaceae, Hydrophyllaceae, Malvaceae, Onagraceae, Portulacaceae, Salicaceae and Solanaceae in North America. The genus includes nearly 1400 described species and is essentially Holarctic in distribution. Adults are usually univoltine, emergent for only about six weeks per year, although a few Old World species are bivoltine. Species in North America are predominantly vernal, although some groups have switched to autumnal emergence. Specialists must time their emergence to coincide with the flowering period of their hosts, thus changes in phenology may be correlated with a host shift or a change in diet breadth. 
One group of specialists within Andrena is the subgenus Callandrena sensu lato Cockerell, consisting of 85 described species which are unusual among North American $\mathrm{An}$ drena for the preponderance of a fall flight season. All but one specialize exclusively on pollen of plants in the Asteraceae, particularly in the tribes Heliantheae, Astereae, Lactuceae, and Helenieae. Together, these four tribes account for $87 \%$ of museum collections attributed to subgenus Callandrena s. $l$. for which a host has been identified. No member of subgenus Callandrena $s$. $l$. is polylectic, but members of the group exhibit host shifts and differences in diet breadth, from narrowly to broadly oligolectic. Thus, subgenus Callandrena s. $l$. is an ideal system in which to study the evolution of these parameters. Only one paper addresses specifically the pollen collection of a species in subgenus Callandrena in detail (Neff and Simpson, 1997). Andrena rudbeckiae is a narrow specialist on Rudbeckia and Ratibida, two closely related taxa (Urbatsch et al., 2000) in the tribe Heliantheae. Although the bee foraged for nectar on other plants in the Asteraceae, it collected pollen only from its two host plants, and nest provisions were entirely of Heliantheae pollen. In this study, we reanalyze a previously published molecular dataset of both nuclear and mitochondrial DNA data (Larkin et al., 2006) to investigate both (1) the evolution of diet breadth and phenology among members of 25 North American subgenera of Andrena and (2) the evolution of host choice within an oligolectic clade within that group. Specifically, we address the following outstanding questions about the evolution of bee diet: Is polylecty ancestral, and does diet proceed towards increasing specialization? Are host shifts mainly to closely related plants? And, do host shifts lead to adaptive radiation?

\section{MATERIALS AND METHODS}

A molecular phylogenetic hypothesis of relationships of 86 species of Andrena in 25 subgenera was generated based on the maximum likelihood (ML) reconstruction of $695 \mathrm{bp}$ of mitochondrial and $676 \mathrm{bp}$ of nuclear data (Larkin et al., 2006). Out- groups included Ancylandrena larreae in the subfamily Andreninae, Protoxaea gloriosa in the Oxaeninae, and six panurgine species. The ML tree was found via an iterative search strategy using progressively more thorough branch swapping algorithms (Danforth et al., 1999).

\subsection{Evolution of diet breadth and phenology}

Diet breadth (oligolectic versus polylectic) and phenology for each species in our phylogeny was based on reports from the literature and on host records from museum specimens. Diet breadth was not determined for outgroup taxa. Phenology was coded for Ancylandrena, as all five known species are spring emergent, but not for the panurgine outgroup species. Characters of phenology (spring, summer, or fall) and diet breadth (oligolectic or polylectic) were mapped onto the phylogenetic tree in MacClade 4.08 (Maddison and Maddison, 2005).

We used the extensive collections of Wallace LaBerge at the Illinois Natural History Survey, Urbana, Illinois, as well as specimens borrowed from the following institutions: California Academy of Sciences, Central Texas Melittological Institute, Kansas State University, Los Angeles County Natural History Museum, Michigan State University, Philadelphia Academy of Natural Sciences, Smithsonian Institution, University of California at Berkeley, University of California at Davis, University of California at Riverside, Utah State University, and Washington State University, and our own collections.

\subsection{Evolution of host choice within an oligolectic clade}

For each species in subgenus Callandrena Clade $\mathrm{B}$, the geographic distribution was mapped in $\mathrm{Ar}$ cView 3.0 (ESRI, 1997) and overlain with a map of vegetation zones (ESRI, 1999) of North America. Up to 20 pollen-bearing females were arbitrarily selected to represent the full range of the geographical distribution, each of the vegetation zones within the distribution, and as many unique collection series as possible. Using a clean insect pin, pollen was removed from deep within the tibial scopal hairs (and propodeal corbicula when filled) to minimize contamination and mounted in glycerine jelly containing basic fuchsin stain. Samples were melted over 


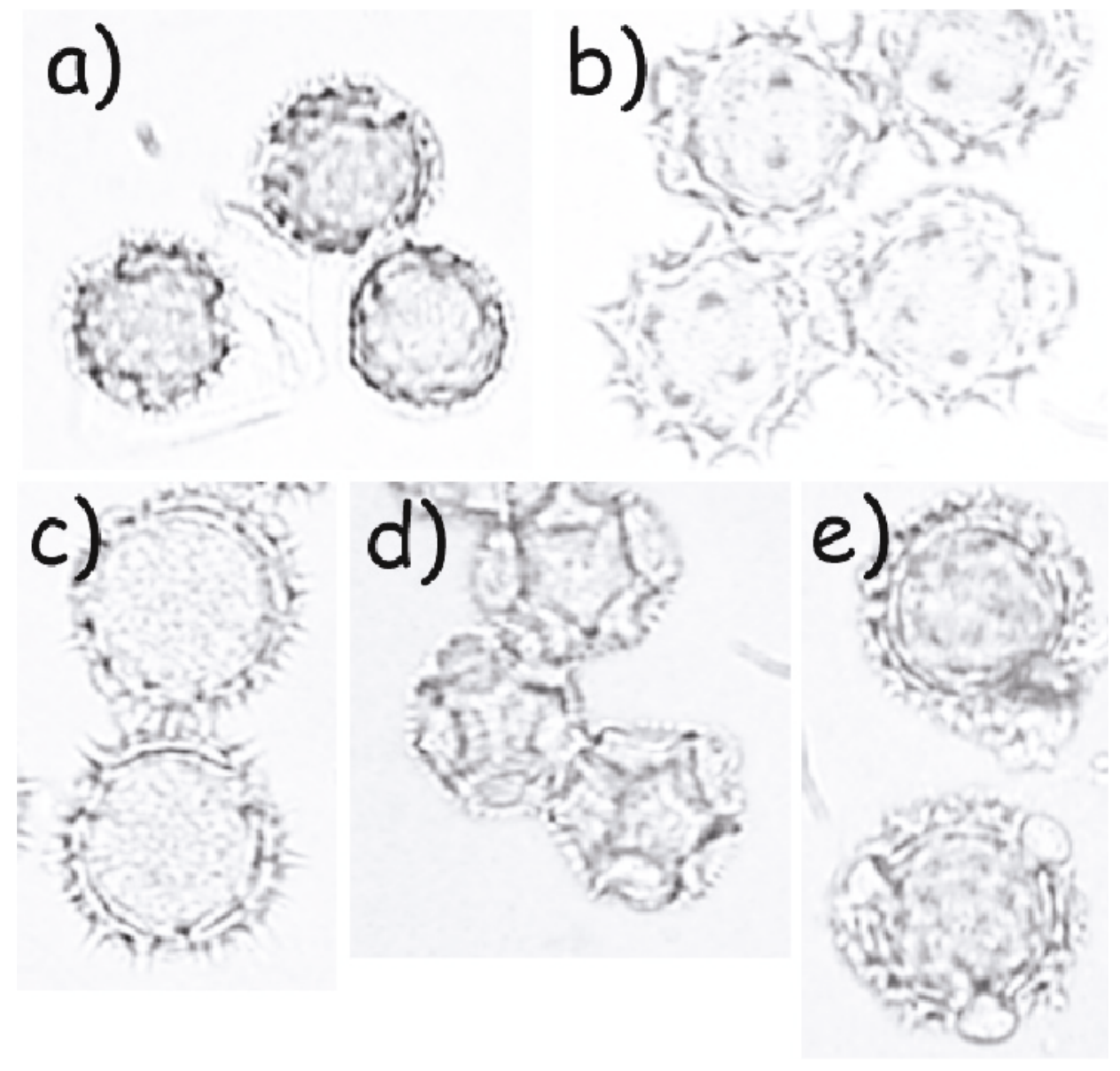

Figure 1. Pollen types within Asteraceae examined in pollen loads of subgenus Callandrena s. l. bees. (a) Astereae-type (Aster), (b) Helenieae-type (Helianthus), (c) Heliantheae-type (Gaillardia), (d) Lactuceaetype (Krigia), (e) Senecioneae-type (Packera/Senecio).

low heat, covered with a cover slip and sealed with clear nail polish. Pollen was analyzed using a Leitz light microscope at a magnification of $400 \times$.

Pollen was characterized by type, based on exine morphology and size, and compared to reference slides of pollen from plants from which bees of that particular species had been previously collected. One hundred grains per slide (when available) were identified. Pollen of Asteraceae is easily distinguished from other angiosperm pollen by its echinate exine surface. Asteraceae pollen was further characterized by tribe as follows: Astereaetype pollen has numerous, short conical spikes; Helenieae-type has fewer, more broadly conical spikes resembling a child's drawing of the sun; Heliantheae-type has numerous long dagger-like spikes; and Lactuceae-type has lacunae enclosed by high echinate ridges (Fig. 1). We could not distinguish Senecioneae pollen from the Astereae-type. When fewer than 100 , but more than 90 , grains were present on a slide, results were scaled to 100 . Slides with fewer than 90 grains were excluded from further consideration. For each bee species, the mean number of pollen grains and standard deviation were calculated for each Asteraceae tribe and for non-Asteraceae pollen.

Bee species were categorized as narrowly oligolectic if the mean number of pollen grains from a host type was $90 \%$ or more of the total pollen and broadly oligolectic otherwise. This loose standard was adopted to allow for the presence of incidental pollen on the bee. Incidental pollen could become 
associated with a bee as pollen unintentionally accumulated during nectar visits to non-pollen host flowers, pollen carryover by another insect to the host plant that was then collected along with host pollen, pollen contamination from other insects during collecting (e.g., in the net, killing jar, or holding jar), or pollen contamination from other museum specimens during storage. It also allows for the occasional bee who may have collected pollen other than from the main host while under ecological duress.

Host identity (pollen type) and degree of specialization (narrowly or broadly oligolectic) were mapped onto the ML tree in MacClade 4.08 (Maddison and Maddison, 2005).

\section{RESULTS}

\subsection{Evolution of diet breadth and phenology}

The ML analysis yielded a single tree of score $-\operatorname{lnL}=24453.419$. Diet breadth was mapped onto this (Fig. 2). In order to simplify the figure, the tree was pruned so that each clade of subgenus Callandrena s. $l$. was represented by only one species. As all species of subgenus Callandrena s. $l$. sampled are oligolectic, this does not affect the mapping of this character. Our data indicate that oligolecty is the ancestral state in the genus, and polylecty has arisen independently several times. The number of times polylecty has evolved and whether there have been any reversals to oligolecty depend on whether equivocal branches are resolved under the ACCTRAN or DELTRAN option. If changes are accelerated (ACCTRAN) on all equivocal branches (Fig. 2a), there were two independent transitions to polylecty followed by seven reversals. Andrena avulsa has reverted to the polylectic state from a secondarily oligolectic ancestor, resulting in three origins of polylecty from an oligolectic ancestor. Alternately, if changes are delayed (DELTRAN) on all equivocal branches (Fig. 2b), ten independent shifts to polylecty occurred with no reversals to oligolecty.

Our data suggest that the ancestor of North American Andrena was a vernal bee (Fig. 3).
Within our phylogeny there have been five independent shifts to autumnal emergence, once each in the ancestors of subgenus Callandrena sensu stricto (Clade A) and of subgenus Callandrena s.l. Clade $\mathrm{C}+\mathrm{D}$, once in the ancestor of subgenus Cnemidandrena, and twice within subgenus Callandrena s.l. Clade B. All five of these phenological transitions involve bees which specialize on hosts in the Asteraceae (vertical bars in Fig. 3).

\subsection{Evolution of host choice within an oligolectic clade}

The results of the pollen load analyses are summarized in Table I. Seventeen of the 28 species were classified as narrow oligoleges and eleven as broad oligoleges. Species specialize on plants in the Asteraceae tribes Astereae (10 spp.), Helenieae (2 sp.), Heliantheae ( 8 spp.), Lactuceae (6 spp.), Senecioneae (1 sp.) and one, A. levipes, on members of the family Polemoniaceae (Tab. I). All six Lactuceae specialists appear to utilize Heliantheae pollen as a secondary host. Andrena afimbriata may be an exception and a narrow oligolege on the Lactuceae, but only four pollen samples were available for examination. Eight of the ten Astereae specialists are narrow oligoleges, while the two broad generalists use alternate hosts in the Helenieae and the Heliantheae, respectively. Andrena gardineri is a broad specialist on Astereae-type pollen, undoubtedly of Packera (Senecioneae) based on label information from museum specimens. Eight species are oligolectic on Heliantheae, two broadly, using alternate hosts in the Astereae and Helenieae, respectively. Andrena berkeleyi and A. melliventris are narrow specialists on pollen of the Helenieae. Finally, A. levipes is a broad oligolege on the Polemoniaceae and utilizes pollen of the Astereae as a secondary host. However, morphology suggests that this species may be misplaced in subgenus Callandrena. Unfortunately, it was not sampled in the molecular phylogeny.

Figure $4 \mathrm{a}$ depicts the host usage of the monophyletic Clade B of subgenus Callandrena s. $l$., as determined from pollen loads. There appear to have been transitions from 

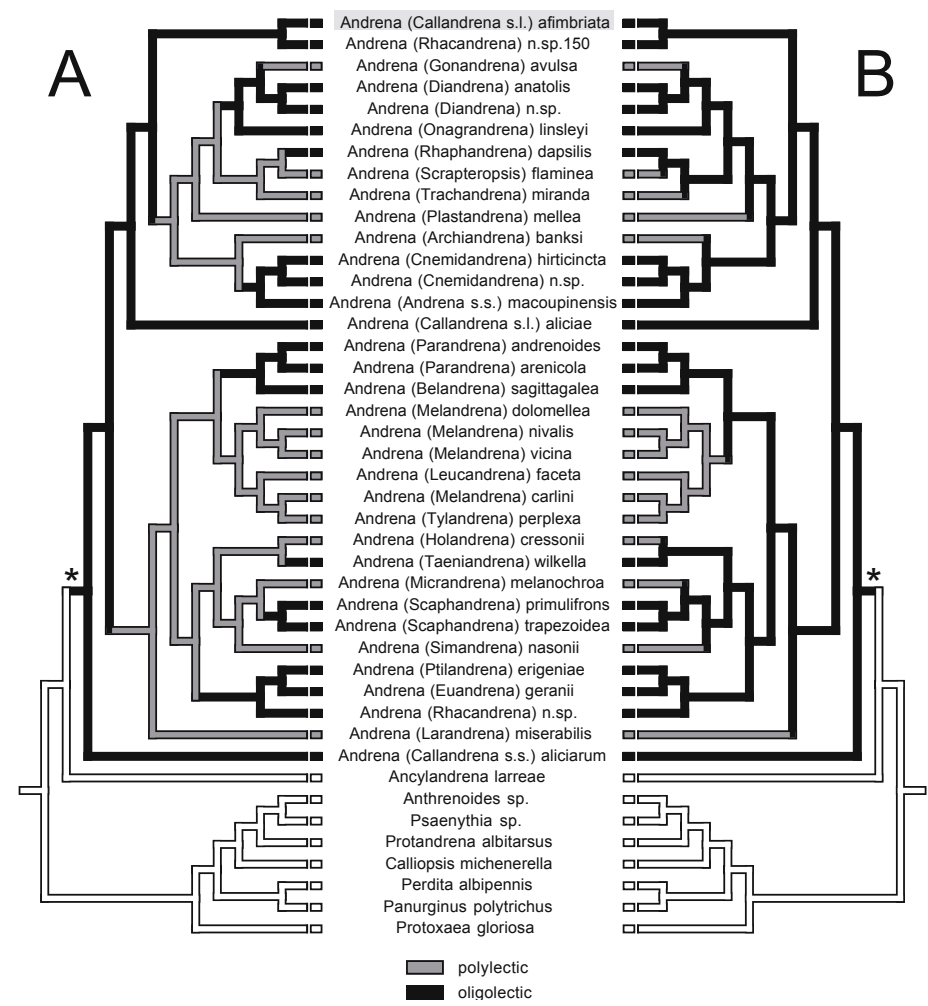

Figure 2. Maximum likelihood molecular phylogeny of Andrena showing diet breadth. Multiple representatives of each subgenus Callandrena s. $l$. clade were pruned for ease of viewing. Asterisks mark the nodes subtending Andrena. Andrena afimbriata, shaded in grey, marks the phylogenetic position of "Clade B". A. ACCTRAN optimization (character transitions accelerated) implies two independent shifts to polylecty with seven reversals to oligolecty and one subsequent secondary evolution of polylecty. B. DELTRAN optimization (character transitions delayed) implies ten independent shifts to polylecty with no reversals to oligolecty.

an ancestral host in the Heliantheae to Senecioneae (in Andrena gardineri), to Lactuceae (in the clade marked "L", Fig. 4a), to Helenieae (in A. melliventris) and to Astereae (in the grade marked "A", Fig. 4a). Within the Lactuceae-using clade have been two reversals to the ancestral host in the Heliantheae in $A$. haynesi and A. tonkaworum, while A. senticulosa facultatively uses hosts in the Heliantheae in addition to its primary hosts in the Lactuceae (unpubl. data, JLN).

There is no apparent phylogenetic pattern to the evolution of diet breadth (Fig. 4b), with a broadening of the diet evolving independently seven times. In all but one case, however, the broadening of diet involves the apparent addition to the diet of the ancestral hosts in the Heliantheae. The exception is Andrena gardineri, which uses members of the Helenieae in addition to its main host in the Senecioneae.

\section{DISCUSSION}

The evolution of diet breadth in bees has been a subject of inquiry in the literature for nearly a century. Modern phylogenetic methods, coupled with microscopic examination of pollen loads on female museum specimens as pioneered by Müller (1996), now allow for 


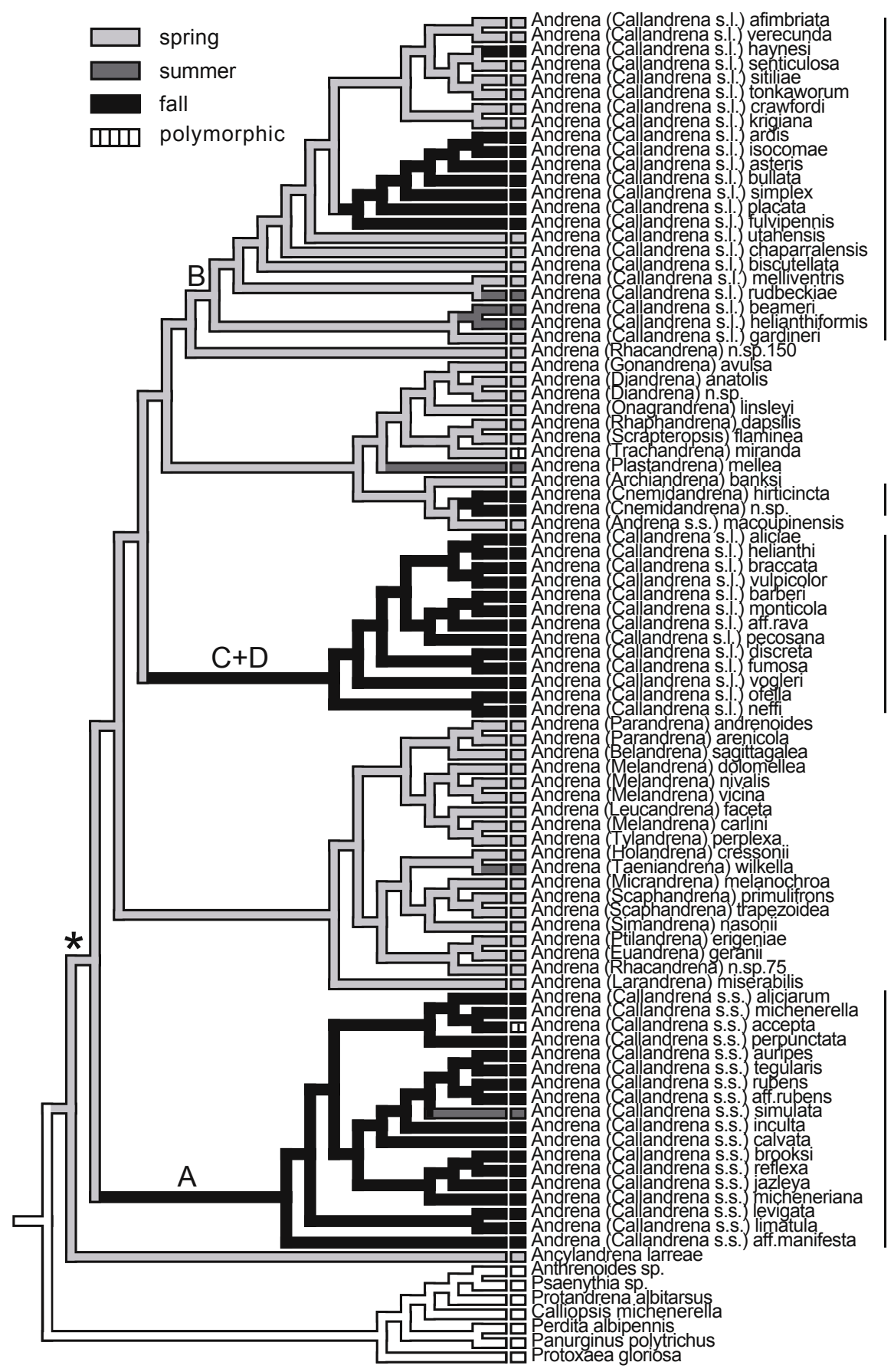

Figure 3. Maximum likelihood molecular phylogeny of Andrena showing season of adult emergence. Two species are coded as polymorphic: Andrena accepta is summer/fall emergent and A. miranda is spring/summer emergent. Outgroups other than Ancylandrena were not coded in this analysis; all species of Ancylandrena are spring emergent. The letters " $\mathrm{A}$ ", "B", and " $\mathrm{C}+\mathrm{D}$ " above the branches mark the clades of Callandrena s. $l$. as in Larkin et al. (2006). 


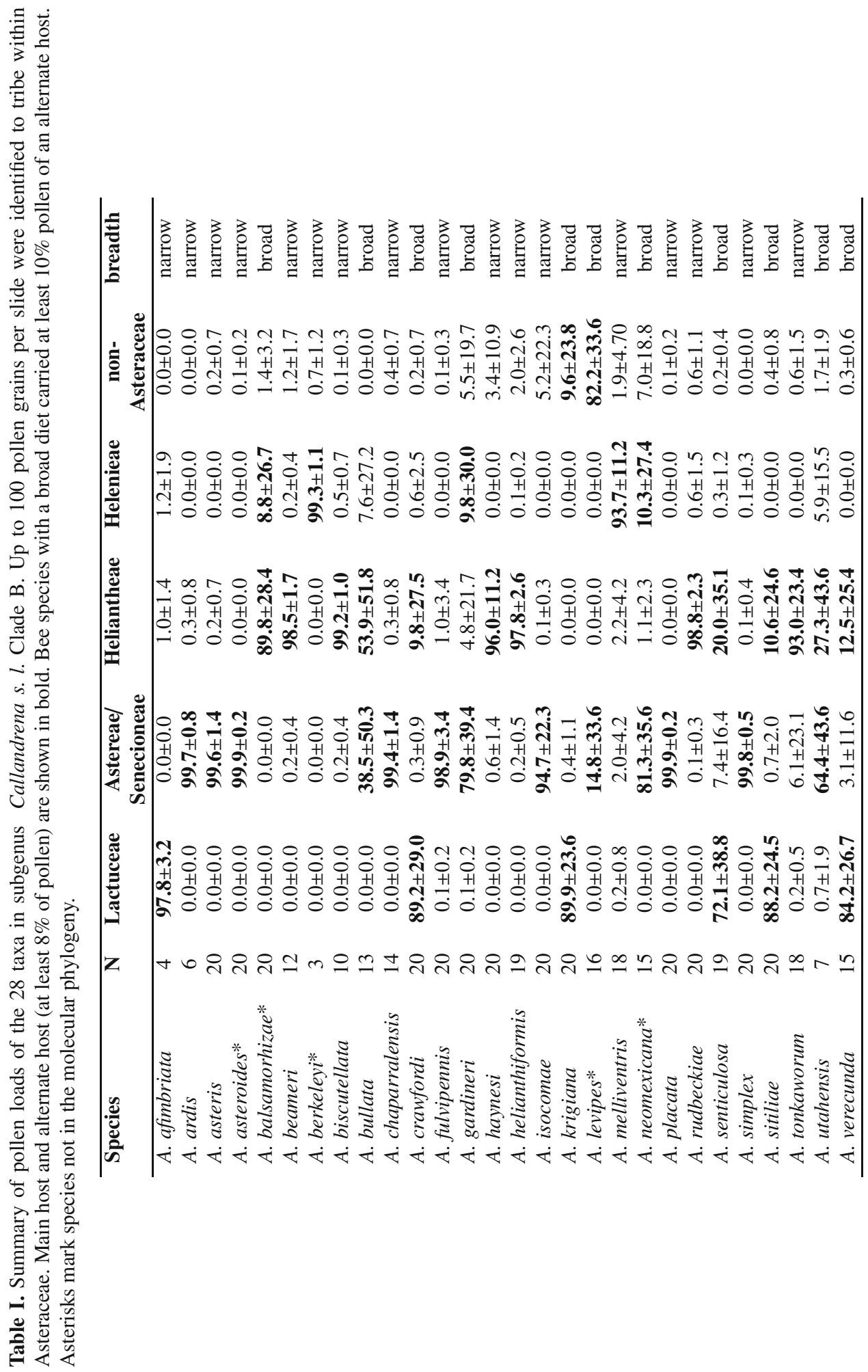



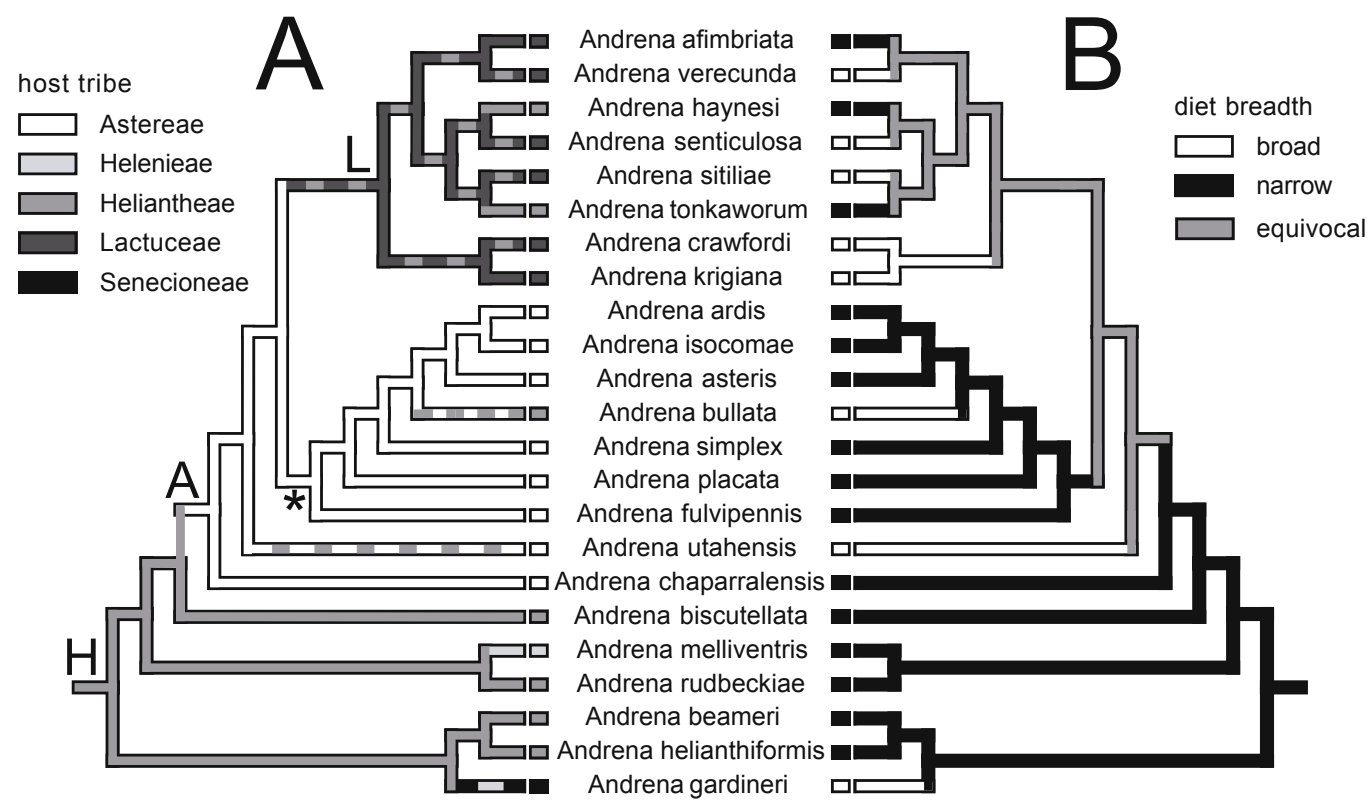

Figure 4. Maximum likelihood molecular phylogeny of Clade B of subgenus Callandrena s. l., showing (A) host tribe as determined from examination of pollen loads and (B) diet breadth based on pollen load data. Letters above the branches denote host-plants in the Heliantheae ("H"), Astereae ("A"), and Lactuceae ("L"). The asterisk marks the fall-emergent clade which has expanded its geographic distribution from a southwestern ancestor to the northeastern United States.

more rigorous tests of hypotheses regarding the evolution of bee diet.

\subsection{Evolution of diet breadth and phenology}

The evolution of specialization within $A n$ drena is particularly interesting in light of the family Andrenidae's placement near the base of short-tongued bees (excluding Melittidae s.l.; Danforth et al., 2006). An understanding of the evolution of specificity in this group could yield insights into the early evolution of bees.

Our data imply that oligolecty is the ancestral state in Andrena. Although we lack Old World exemplars in our phylogeny, this conclusion is supported by a number of facts. First, Andrena evolved in North America, so the basal clades in our analyses are likely the basal clades in Andrena worldwide. Second, the subgenus Callandrena s. $s$. is well supported as the basal clade in the genus, and all members of Callandrena s. s. are oligolectic. Third, the two genera most closely related to Andrena, Megandrena and Ancylandrena, are apparently also oligolectic, suggesting that not only was the ancestor of Andrena oligolectic, but the ancestor of Andrena plus its sister genera was oligolectic as well.

The suggestion that oligolecty may be ancestral in some or all bees is not unique to this study. Michez et al. (2008) found that three of the five genera in their study could have oligolectic ancestors. Circumstantial evidence for oligolecty as the ancestral condition lies in the observations by both Michez et al. and Müller (1996) that shifts from oligolecty to polylecty are more frequent than the reverse. This is counter to the results of meta-analyses of 15 studies of phytophagous insects (Nosil, 2002; Nosil and Mooers, 2005), which suggest that evolutionary transitions in diet breadth toward specialization (rather than toward generalization) are more common. In Andrena, the relative number of shifts between oligolecty 
and polylecty depends on the optimization strategy (Fig. 3). Under ACCTRAN optimization, polylecty has evolved independently at least twice, followed by at least seven reversals to specialist behavior and one secondary evolution of polylecty. This suggests that a narrowing of the diet is more common. Under DELTRAN optimization, however, there were ten independent transitions to polylecty and no reversals to oligolecty, indicating that broadening of the diet occurs more frequently. Under both optimization strategies, diet breadth is quite labile, with at least ten transitions seen among 86 species of Andrena.

\subsection{Evolution of host choice within an oligolectic clade}

The ancestor of Clade B appears to have been an oligolectic bee specializing on $\mathrm{He}$ liantheae (Fig. 4a). A transition to host plants in the Astereae ("A" in Fig. 4a) led to a series of speciation events and to a subsequent shift to Lactuceae ("L", Fig. 4a). In the Astereae grade and in the Lactuceae clade are six species (dashed lines in Fig. 4a) that collect pollen from both their novel host and from the Heliantheae, suggesting the evolutionary retention of the ability to use the ancestral host. In fact, $A$. senticulosa, uses both Lactuceae (preferred) and Heliantheae pollen facultatively (JLN, unpubl. data).

Our data suggest that oligolectic bees are phylogenetically limited in their choice of host in that sister species generally use hosts in the same plant tribe. However, host shifting is common within a plant tribe. Sympatric sister species almost always use different hosts; for example, Andrena krigiana, which may have given rise to A. crawford $i$ in Texas, is a specialist on Krigia (Lactuceae) throughout its range, but its sister species specializes on Pyrrhopappus (Lactuceae). This phylogenetic constraint in host preference is occasionally overcome, with an evolutionary transition to pollen hosts in another tribe of Asteraceae. Although we examine only one clade, our data suggest that such transitions do lead to adaptive radiation: the Astereae grade includes nine of the 23 species in the phylogeny $(39.1 \%)$, and the
Lactuceae clade includes eight (34.7\%). Thus, nearly three-fourths of the diversity in Clade B evolved subsequent to evolutionary transitions to novel hosts.

Diet breadth within Clade B showed no obvious pattern; with independent transitions to a broader diet in specialists on all three host-plant tribes. As with the evolution of diet breadth on a genus level, the exact number of transitions to a broader diet and whether there were reversals from broadly to narrowly oligolectic depends on the resolving options. Sipes and Tepedino (2005) found a similar pattern in Diadasia bees. Unlike in Andrena, however, they found no evidence for bees retaining the ability to use an ancestral host. A higher tendency to colonize ancestral hosts, as seen in Andrena, has been observed in some phytophagous insects (Janz et al., 2001; Janz and Nylin, 1998).

\subsection{Phenology}

The ancestral state of Nearctic Andrena is apparently vernal activity. There have been at least five independent transitions to autumnal emergence in North America, all of which are in clades of composite-specialists, suggesting a correlation between fall activity and host plants in the Asteraceae. An interesting transition has occurred within a grade of species that have switched to Astereae (Figs. 3, 4). Two species basal to the Astereae clade, $A$. chaparralensis and $A$. utahensis, have retained the ancestral vernal state and occur in Texas and the southwestern United States, while the remainder of the clade has shifted to autumnal activity. The shift to fall activity has also involved a movement into the northeastern United States; presumably, the ability to use Astereae hosts was a preadaptation to the use of the fall-flowering Astereae of the northeastern U.S.

\section{CONCLUSIONS}

Our results indicate that oligolecty is the ancestral state in Andrena and that polylectic bees can and do evolve from more specialized 
ancestors. In fact, diet breadth is somewhat labile, with ten transitions between oligolecty and polylecty appearing in a phylogeny of 86 species. In addition, specialists often retain the ability to use the pollen-host of their ancestors. These two observations together contradict the popular notion that specialization is an evolutionary "dead end". Within the oligolectic clade we studied, host shifts are predominantly to related hosts plants (within the same Asteraceae tribe), implying a phylogenetic constraint, and shifts to more distant hosts may lead to adaptive radiation. The patterns we see in the evolution of diet in Andrena are similar to patterns seen in the evolution of diet in many phytophagous insects.

\section{ACKNOWLEDGEMENTS}

We thank the curators of the museums from which we borrowed specimens for the use of their material. The manuscript was substantially improved by the comments of B. Danforth and two anonymous reviewers. This research was funded in part by United States National Science Foundation grants to BBS and LLL (DEB 9902301) and to LLL (DEB 0344288).

Évolution d'un régime pollinique : choix de l'hôte et spectre alimentaire des andrènes (Hymenoptera : Andrenidae).

Andrena / spectre alimentaire / choix de l'hôte / pollen / spécialisation

Zusammenfassung - Die Evolution der Pollenernährung: Wahl der Wirtspflanzen und Breite des Nahrungsspektrums von Andrena Bienen (Hymenoptera: Andrenidae). Ebenso wie pflanzenfressende Insekten weisen Bienen eine ausgeprägte Variabilität in der Breite des Nahrungsspektrums auf, das von breit angelegten Generalisten (polylektisch) bis zu engen Spezialisten (oligolektisch) reicht. Üblicherweise wurde angenommen, dass sich die Ernährung in Richtung zunehmender Spezialisierung entwickelt, obwohl die wenigen wegbereitenden Untersuchungen, in denen der Versuch unternommen wurde die Evolution der Pollenspezifität zum Gegenstand zu machen, nicht von rigorosen phylogenetischen Hypothesen getragen wurden. In diesem Artikel untersuchen wir zwei Gesichtspunkte der Pollenernährung innerhalb der
Bienengattung Andrena (Andrenidae): (1) die Evolution der Breite des Nahrungsspektrums innerhalb der nordamerikanischen Vertreter der Gattung, die sowohl polylektische als auch oligolektische Arten einschließt und (2) die Wahl der Wirtspflanzen innerhalb einer oligolektischen Linie von Andrena. Wir untersuchen weiterhin (3) die Evolution der Phänologie.

Zunächst erzeugten wir eine molekulare maximum likelihood Phylogenie von 86 Andrena Arten zusammen mit acht Außengruppen, indem wir die Daten einer zuvor veröffentlichten Phylogenie reanalysierten. Die Breite des Nahrungsspektrums (Abb. 2; aus der Literatur ermittelt) und die Phänologie (Abb. 3; aus Museumssammlungen und der Literatur) wurden daraufhin auf die Phylogenie kartiert, um die ursprünglichen Eigenschaften zu ermitteln. Innerhalb eines gut belegten monophyletischen Kladus von 28 oligolektischen Andrena Arten identifizierten wir die Wirtspflanzen, indem wir aus bis zu 20 weiblichen, die Verbreitung abdeckenden Museumsexemplaren pro Art entnommenen Pollen mikroskopisch untersuchten. Bis zu 100 Pollenkörner pro Art wurden bis zum Pflanzentribus innerhalb der Asteraceaen identifiziert (Abb. 1, Tab. I). Die Identität der Wirtspflanzen wurde dann auf die Phylogenie dieses Kladus kartiert (Abb. 4).

Insgesamt, (1) erscheint die Oligolektie innerhalb Andrena der ursprüngliche Zustand zu sein und sich breitere Nahrungsspektren dann mehrere Male entwickelt zu haben. Dies legt nahe, dass Spezialisierung keine evolutionäre Sackgasse darstellt. Innerhalb der untersuchten Kladen der Untergattung Callandrena s. l., (2) traten Wechsel der Wirtspflanzen überwiegend zwischen Mitgliedern der gleichen Tribi der Asteraceae auf, dies weist auf eine phylogenetische Einschränkung der Wirtspflanzennutzung hin. Nichtsdestoweniger sind Wechsel zu anderen Tribi nicht ungewöhnlich und könnten zu adaptiven Radiationen führen. Darüber hinaus behalten einige Linien die Fähigkeit Pollen eines ancestralen Tribus von Wirtspflanzen zu nutzen. $\mathrm{Zu}-$ letzt (3) finden wir eine Korrelation zwischen der Nutzung von Wirtspflanzen innerhalb der Familie der Asteraceae und dem Schlupf im Herbst. Unsere Ergebnisse zeigen Parallelen zu Untersuchungen der Breite des Wirtsspektrums und der Wirtswahl bei pflanzenfressenden Insekten.

Andrena / Breite des Nahrungsspektrums / Wirtswahl / Pollen / Spezialisierung

\section{REFERENCES}

Bernays E.A. (1988) Host specificity in phytophagous insects: Selection pressure from generalist predators, Entomol. Exp. Appl. 49, 131-140.

Bernays E.A. (2001) Neural limitations in phytophagous insects: Implications for diet breadth 
and evolution of host affiliation, Annu. Rev. Entomol. 46, 703-727.

Bernays E.A., Chapman R.F. (1994) Host-plant selection by phytophagous insects, Chapman \& Hall, New York.

Cane J.H., Snelling R.R., Kervin L.J. (1996) A new monolectic coastal bee, Hesperapis oraria Snelling and Stage (Hymenoptera: Melittidae), with a review of desert and neotropical disjunctives in the Southeastern U.S., J. Kans. Entomol. Soc. 69, 238-247.

Cruden R.W. (1972) Pollination biology of Nemophila menziesii Hydrophyllaceae with comments on the evolution of oligolectic bees, Evolution 26, 373389.

Danforth B.N., Sauquet H., Packer L. (1999) Phylogeny of the bee genus Halictus (Hymenoptera: Halictidae) based on parsimony and likelihood analysis of nuclear EF-1a sequence data, Mol. Phylogenet. Evol. 13, 605-618.

Danforth B.N., Conway L., Ji S. (2003) Phylogeny of eusocial Lasioglossum reveals multiple losses of eusociality within a primitively eusocial clade of bees (Hymenoptera: Halictidae), Syst. Biol. 52, 23-36.

Danforth B.N., Sipes S.D., Fang J., Brady S.G. (2006) The history of early bee diversification based on five genes plus morphology, Proc. Natl. Acad. Sci. USA 103, 15118-15123.

ESRI (1997) ArcView 3.0a for Power MacIntosh 3.0a, Environmental Systems Research Institute, Inc., Redlands, CA.

ESRI (1999) World Vegetation (WMS), Environmental Systems Research Institute, Inc., Redlands, CA.

Faegri K., van der Pijl L. (1979) The Principles of Pollination Ecology, 3rd ed., Pergamon Press, Oxford.

Guirguis G.N., Brindley W.A. (1974) Insecticide susceptibility and response to selected pollen of larval alfalfa leaf-cutting bees, Megachile pacifica (Hymenoptera: Megachilidae), Environ. Entomol. 3, 691-694.

Hurd P.D. Jr., LaBerge W.E., Linsley E.G. (1980) Principal sunflower bees of North America with emphasis on the southwestern United States (Hymenoptera: Apoidea), Smithson. Contrib. Zool. 310, 1-158.

Iwata K. (1976) Evolution of instinct. Comparative Ethology of Hymenoptera. Amerind, New Delhi, India.

Jaenike J. (1990) Host specialization in phytophagous insects, Annu. Rev. Ecol. Syst. 21, 243-273.

Janz N., Nylin S. (1998) Butterflies and plants: A phylogenetic study, Evolution 52, 486-502.

Janz N., Nyblom K., Nylin S. (2001) Evolutionary dynamics of host-plant specialization: A case study of the tribe Nymphalini, Evolution 55, 783-796.
Kratochwil A. (1984) Pflanzengesellschaften und Blütenbesucher-Gemeinschaften: biozönologische Untersuchungen in einem nicht mehr bewirtschafteten Halbtrockenrasen (Mesobrometum) im Kaiserstuhl (Südwestdeutschland), Phytocoenologia 11, 455-669.

Kratochwil A. (1991) Blüten-/BlütenbesucherKonnexe: Aspekte der Co-Evolution, der CoPhänologie unde der Biogeographie aus dem Blickwinkel unterschiedlicher Komplexitätsstufen, Ann. Bot. 49, 43-108.

Larkin L.L. (2002) Phylogeny and floral host relationships of Callandrena (Hymenoptera: Andrenidae: Andrena), Ph.D. Dissertation, University of Texas at Austin, Austin, Texas.

Larkin L.L., Neff J.L., Simpson B.B. (2006) Phylogeny of the Callandrena subgenus of Andrena (Hymenoptera: Andrenidae) based on mitochondrial and nuclear DNA data: Polyphyly and convergent evolution, Mol. Phylogenet. Evol. 38, 330-343.

Levin M.D., Haydak M.H. (1957) Comparative value of different pollens in the nutrition of Osmia lignaria Say, Bee World 38, 221-226.

Linsley E.G. (1958) The ecology of solitary bees, Hilgardia 27, 543-599.

Linsley E.G., MacSwain J.W. (1958) The significance of floral constancy among bees of the genus Diadasia (Hymenoptera, Anthophoridae), Evolution 12, 219-223.

MacSwain J.W., Raven P.H., Thorp R.W. (1973) Comparative behavior of bees and Onagraceae. IV. Clarkia bees of the western United States, Univ. Calif. Publ. Entomol. 70, 1-80.

Maddison D.R., Maddison W.P. (2005) MacClade 4.08. Sinauer Associates, Inc., Sunderland, MA.

Mayhew P.J. (1997) Adaptive patterns of host-plant selection by phytophagous insects, Oikos 79, 417428.

Michener C.D. (1954) Bees of Panamá, Bull. Am. Mus. Nat. Hist. 104, 1-176.

Michener C.D. (2007) The Bees of the World, 2nd ed., Johns Hopkins Press, Baltimore, MD.

Michez D., Patiny S., Rasmont P., Timmermann K., Vereecken N.J. (2008) Phylogeny and hostplant inheritance in Melittidae sensu lato (Hymenoptera: Apoidea), Apidologie 39, 146-162.

Moldenke A.R. (1979a) Host-plant coevolution and the diversity of bees in relation to the flora of North America, Phytologia 43, 357-419.

Moldenke A.R. (1979b) The role of host-plant selection in bee speciation processes, Phytologia 43, 433-460.

Müller A. (1996) Host-plant specialization in western Palearctic Anthidiine bees (Hymenoptera: Apoidea: Megachilidae), Ecol. Monogr. 66, 235257. 
Neff J.L., Simpson B.B. (1997) Nesting and foraging behaviour of Andrena (Callandrena) rudbeckiae Robertson (Hymenoptera: Apoidea: Andrenidae) in Texas, J. Kans. Entomol. Soc. 70, 100-113.

Nosil P. (2002) Transition rates between specializa tion and generalization in phytophagous insects, Evolution 56, 1701-1706.

Nosil P., Mooers A.Ø. (2005) Testing hypotheses about ecological specialization using phylogenetic trees, Evolution 59, 2256-2263.

Robertson C. (1925) Heterotropic bees, Ecology 6, $412-436$.

Sipes S.D., Wolf P.G. (2001) Phylogenetic relationships within Diadasia, a group of specialist bees, Mol. Phylogenet. Evol. 19, 144-156.

Sipes S.D., Tepedino V.J. (2005) Pollen-host specificity and evolutionary patterns of host switching in a clade of specialist bees (Apoidea: Diadasia), Biol. J. Linn. Soc. 86, 487-505.
Thomson J.D., Wilson P., Valenzuela M., Malzone M. (2000) Pollen presentation and pollination syndromes, with special reference to Penstemon, Plant Species Biol. 15, 11-29.

Urbatsch L.E., Baldwin B.G., Donoghue M.J. (2000) Phylogeny of the coneflowers and relatives (Heliantheae: Asteraceae) based on nuclear rDNA internal transcribed spacer (ITS) sequences and chloroplast DNA restriction site data, Syst. Bot. 25, 539-565.

Wcislo W.T., Cane J.H. (1996) Floral resource utilization by solitary bees (Hymenoptera: Apoidea) and exploitation of their stored foods by natural enemies, Annu. Rev. Entomol. 41, 257-286.

Williams N.M. (2003) Use of novel pollen species by specialist and generalist solitary bees (Hymenoptera: Megachilidae), Oecologia 134, 228-237. 